\title{
JOANNA SMARŻ'
}

\section{Administration - Regulatory or Mediating?2}

Submitted: 18.10.2021. Accepted: 23.05.2021

\begin{abstract}
Mediation in the administrative procedure is a new institution that provides a chance for an improved perception of public administration, yet it also gives rise to a range of doubts. The latter spring chiefly, though not solely, from the nature of administrative control. The principles of the rule of law, objective law, and voluntary mediation, which may be taken an improper advantage of, contrary to the legislator's intentions, are also identified as barriers.

Analysis of the issue implies that administrative proceedings leave room for mediation. Whether it will fulfil expectations, however, largely depends on the attitudes of parties and administrative authorities, or their employees, to be precise, for whom mediation is undoubtedly both a processual and mental challenge.

The introduction of mediation to the Code of Administrative Procedure is to be applauded, mainly from the perspective of inducing citizens' trust in public authorities. Mediation may also prove an effective instrument of eliminating conflicts in administration and thus contribute to reducing the caseload to be heard by administrative courts.

It is important, though, for this opportunity to be taken proper advantage of and for the transformation of administration from controlling to mediating and more friendly to subjects administered to continue. This is a trend that deserves to be followed not only in Polish but also other legislations.
\end{abstract}

Keywords: mediation, amicable dispute resolution, administrative proceedings, Code of Administrative Procedure.

1 Prof. UTH Joanna Smarż, PhD - Kazimierz Pułaski University of Technology and Humanities in Radom (Poland); e-mail: jsmarz@op.pl; j.smarz@uthrad.pl; ORCID: 0000-0002-2450-8162.

2 The research project is not financed by any institution. 


\section{JOANNA SMARŻ}

\section{Administracja władcza czy mediacyjna ${ }^{3}$}

\section{Streszczenie}

Mediacja w procedurze administracyjnej jest nową instytucją, dającą szansę na bardziej przyjazne postrzeganie administracji publicznej, ale stwarzającą też wiele wątpliwości. Wynikają one przede wszystkim z charakteru władztwa administracyjnego organów administracji, ale nie tylko. Jako barierę wskazuje się bowiem także zasadę praworządności i prawdy obiektywnej oraz zasadę dobrowolności mediacji, która może zostać wykorzystana w niewłaściwy sposób, sprzeczny z założeniami ustawodawcy.

Jak wynika z analizy tytułowego zagadnienia, w postępowaniu administracyjnym jest miejsce na mediację. Jednak to, czy spełni ona pokładane w niej nadzieje, zależy w dużej mierze od postawy stron i organów administracji, a właściwie jej pracowników, dla których mediacja stanowi niewątpliwie wyzwanie w płaszczyźnie nie tylko procesowej, lecz także mentalnościowej.

Wprowadzenie mediacji do k.p.a. należy ocenić pozytywnie przede wszystkim w odniesieniu do realizacji zasady wzbudzania zaufania obywateli do władzy publicznej. Mediacja może też stanowić skuteczny instrument eliminowania konfliktów $\mathrm{w}$ administracji, a przez to również przyczynić się do ograniczenia liczby spraw wymagających rozpatrzenia przez sądy administracyjne.

Ważne jednak, aby stworzona szansa została właściwie wykorzystana i aby nastąpiła dalsza transformacja charakteru administracji z władczej na mediacyjną, bardziej przyjazną podmiotom administrowanym. Jest to trend nie tylko polskiego ustawodawstwa, lecz także innych państw, za którym powinniśmy podążać.

Słowa kluczowe: mediacja, polubowne rozstrzyganie sporów, postępowanie administracyjne, kodeks postępowania administracyjnego.

3 Badania nie są finansowane przez żadną instytucję. 


\section{Introduction}

Although mediation, as an amicable way of dispute resolution, has been known for long, it has recently developed at a particularly rapid rate, mainly in penal and civil cases. ${ }^{4}$ It has also become a major novelty in regulations of administrative proceedings.

Introducing mediation to public law is not free from controversies, however, chiefly due to the superior status of an authority, provided as it is with administrative control. This is not the sole impediment to mediation becoming entrenched in administrative proceedings.

This paper analyses changes to administrative actions caused by introducing mediation to administrative procedure and indicates some consequent problems.

\section{Administrative Control}

The introduction of mediation to public law continues to give rise to doubts. The following question needs to be answered: does a party to a dispute, i.e. an administrative authority, has control over the other in mediation ${ }^{5}$ Functioning of public administration relies on administrative control $^{6}$, characterised by the ability of a public administrative authority to unilaterally determine the rights and duties of a private entity by means of control $^{7}$ that ensures obedience. ${ }^{8}$

The control consists in a final act of volition by an authority determining the contents of a legal relationship and is rarely based on free discretion. Authority, which should derive not from force, but from trust in authorities ${ }^{9}$, is an additional

E. Talma, Mediation as an Alternative Method of Dispute Resolution, "Casus" 2019, 92, p. 63.

$5 \quad$ K. Płeszka, M. Araszkiewicz, [in:] M. Araszkiewicz, J. Czapska, M. Pękala, K. Płeszka (eds.), Mediacja. Teoria, normy, praktyka, Warszawa 2017, pp. 69-70.

6 J. Borkowski, The Notion of Administrative Control, Acta Universitatis Wratislaviensis, "Review of Law and Administration II" 1972, 167, p. 46; A. Skóra, The Idea of Mediation in Administrative Proceedings, "Mediator" 2004, 29(2), pp. 54-55.

7 B. Majchrzak, Problems of Defining Administrative Law (Based on Views in the Doctrine), "Public Law Quarterly" 2006, 3, p. 156.

8 E. Ochendowski, Prawo administracyjne. Część ogólna, Torun 1999, p. 24.

9 W. Taras, Power - Public Administration - Trust, [in:] Administrative Control. Public Administration in the Spheres of Empire and Dominion, Rzeszów 2012, p. 696. 
element of state power. I. Skrzydło-Niżnik ${ }^{10}$ is right to note that control is not a privilege of administration in its relation with private entities. The possibility of applying control means the duty to act and it is in a way incumbent upon authorities. J. Szreniawski is of a similar view, stating an official should be aware that they are representatives of a democratic state with control at their disposal, yet they are first of all suppliers of administrative services, whose activities are primarily expected to serve citizens. ${ }^{11}$

Controlling functions of public administrative authorities are methods of discharging public duties that must be grounded in law. Therefore, it can be said that controlling rights and duties of the public administrative authorities are the consequences of provisions contained in legal norms. ${ }^{12}$

In view of the above, the institution of mediation may seem not to fit the nature of public administration. ${ }^{13}$ It should be noted, though, administrative law, in spite of its wide-ranging control, seeks solutions to address the changing nature of conflicts. Many decisions diverge at present from the classic formula of the controlling application of law, while the future addressees of resolutions are increasingly involved in the process of the controlling instantiation of a legal norm. A decision is thus a result of a compromise.

Noting the tendency, M. Zimmermann wrote years ago: '[A]s society consolidates and specialisation proceeds, the influence of citizens on legal life is likely to increase', while the 'expansion of democracy towards the increased influence of citizens on both the creation of legal norms itself and involvement in the creation of administrative acts that affect individuals, wide-ranging social control, and enhanced social solidarity will make the state compulsion a genuinely ultimate guarantee'. ${ }^{14}$

J. Starościak raises similar opinions, emphasising that the unilateral nature of the relationship should no longer be seen as absolute and the proposition that parties to the relationship are unequal should be 'corrected'. The author points out that even the most classic unilateral administrative resolutions become effective as a result of far-reaching negotiations and arrangements between administrative authorities

10 I. Skrzydło-Niżnik, Essence and Types of Controlling Powers of State Administration, "Cracow Law Studies" 1987, 20, p. 126.

11 J. Szreniawski, Zagadnienia relacji pracowników administracji publicznej z obywatelami w modernizującym się państwie, „Administracja. Teoria-Dydaktyka-Praktyka” 2011, 4(25), p. 94.

12 P. Radziewicz, Administrative Legal Concept of Public Control, "Public Law Quarterly" 2005, 4, pp. 133-134.

13 A. Wójcik, Mediacja jako nowy instrument znowelizowanego kodeksu postępowania administracyjnego w ksztattowaniu nowoczesnej administracji, „Młody Jurysta” 2018, 4, p. 90, and K. Kowalczyk, Instytucja mediacji i jej znaczenie w administracji publicznej, "ADR Arbitraż i Mediacja” 2019, 2, p. 53.

14 M. Zimmermann, Pojęcie administracji publicznej a "swobodne uznanie", Poznań 1959, p. 61. 
and citizens. ${ }^{15} \mathrm{~J}$. Łętowski points to the need for an authority to reach an 'agreement' with the recipients of a decision. ${ }^{16}$

Therefore, it can be assumed that the doctrine allows for arrangements between administrative authorities and private individuals, though the extent of such arrangements will vary depending on the intensity of control. The greater the extent of an administrative authority's freedom of decision-making, the greater chances of success for mediation. ${ }^{17}$ The extent is certain to be broader in the case of decisions made at administrative discretion and of indeterminate phrases. ${ }^{18}$ Since norms of substantive law allow for the choice of legal consequences, methods of case resolution can be determined by parties to mediation.

The question of the mediation-based nature of cases resolved by way of constrained decisions is more complex, since the 'constraint' does not allow an authority freedom of decision. As the authority is bound to make a single decision in the face of factual circumstances, there is no room for mediation in the case. This does not mean that a party cannot be treated as a partner. A controlling action of an authority does not preclude certain arrangements with a party in order to lead to a legal decision whose contents will match the interests of both parties and the authority. Participants in mediation may negotiate even in such cases, although the negotiations would concern other issues, e.g. dates by which obligations imposed by the authority must be discharged.

\section{Existing Solutions That Allow for an Amicable Dispute Resolution}

Before mediation was introduced to the Code of Administrative Procedure ${ }^{19}$, the idea of alternative dispute resolution $\left(\mathrm{ADR}^{20}\right)$ under administrative law had been realised to a very limited extent, although the Code provided for several solutions

15 J. Starościak, System prawa administracyjnego, Vol. III, T. Rabska, J. Łętowski (eds.), Warszawa 1977, pp. $22-23$.

16 J. Łętowski, Prawo administracyjne dla każdego, Warszawa 1995, pp. 184-185.

17 Z. Kmieciak, Mediation in Polish Administrative Law, [in:] H. Machińska (ed.), Mediation in Administrative Cases, Warszawa 2007, p. 40.

18 K. Klonowski, [in:] H. Knysiak-Sudyka (ed.), Code of Administrative Procedure: Commentary, Warszawa 2019, p. 633; B. Adamiak, [in:] B. Adamiak, J. Borkowski, Code of Administrative Procedure: Commentary, Warszawa 2019, p. 543; M. Jaśkowska, [in:] R. Hauser, Z. Niewiadomski, A. Wróbel (eds.), Instytucje prawa administracyjnego. System prawa administracyjnego, Vol. 1, Warszawa 2010, p. 260; A. Bródka, Dopuszczalność oraz zakres prowadzenia mediacji w postępowaniu administracyjnym, „ADR Arbitraż i Mediacja” 2020,1, p. 30.

19 J. Smarż, Instytucja mediacji w postępowaniu administracyjnym, "The Opole Studies in Administration and Law" 2018, 161(4), pp. 61-70.

20 ADR - Alternative Dispute Resolution. 
in this respect. ${ }^{21}$ The principle of persuasion, which allows a party to influence a resolution, needs to be mentioned. Administrative settlement, supposed to allow parties active participation in arrival at dispute resolutions, is worth noting as well. This institution is believed to have failed expectations ${ }^{22}$, as the legislation did not provide for a party to enter arrangements with an administrative authority. As a result, the doctrine regarded it as not up to the contemporary standards and requirements of the soft law. ${ }^{23}$

Opportunities for applying mediation were also offered by the institution of administrative approval, empowering an authority to select one of several available resolutions to a case. Article 7 of the Code of Administrative Procedure, which binds an authority to take all steps needed to accurately establish factual circumstances and settle a case with due regard to the public interest and fair interests of citizens, is important in this connection. ${ }^{24}$

In spite of the solutions in place, criticism was raised that the Code of Administrative Procedure does not provide sufficient regulation for the procedure of alternative resolution. ${ }^{25}$ Mediation failed to fulfil its role in court administrative proceedings too. It could only be applied at the stage of dispute, after the pre-court procedure before the first and second instance authorities has been completed, when the parties have submitted their reasons, arguments and expectations, which made a compromise difficult. ${ }^{26}$ Therefore, providing for amicable dispute resolution as early as at the stage of administrative proceedings to prevent instigation of court administrative proceedings is an argument for introducing mediation to the Code of Administrative Procedure. ${ }^{27}$

21 Reasons for the draft act amending the Code of Administrative Procedure and certain other acts, and draft executive acts, Bill, No. 1183, pp. 34-35.

22 Z. Kmieciak, Mediation and Conciliation in Administrative Law, Cracow 2004, p. 106.

23 A. Krawczyk, Administrative Procedural Law, "System of Administrative Law" 2014, 9, 2014, p. 47.

24 T. Frey, Office - Citizen Relation and Good Administrative Standards, Warszawa 2007, pp. 183 ff, and P.M. Głąba, Mediacyjna koncepcja ustalania stanu faktycznego w postępowaniu administracyjnym, „ADR Arbitraż i Mediacja” 2012,3 .

25 J. Wegner-Kowalska, The Case for Including Mediation in the Code of Administrative Procedure, "Public Law Review" 2016, 11, p. 55, and J. Wegner-Kowalska, The Idea of Mediation in Administrative Proceedings, "Public Law Review" 2016, 10, p. 93 ff, and idem, Mediation in Administrative Cases - Questions and Doubts, "Research Papers of Administrative Judicature" 2017, 6, pp. 74-75.

26 Z. Kmieciak, Mediation in Polish..., op. cit., pp. 41-42, and idem, Postępowanie mediacyjne i uproszczone przed sq̨dem administracyjnym, „Państwo i Prawo” 2003, 10, p. 28.

27 Z. Kmieciak, Mediation and Conciliation..., op. cit., p. 133. 
As a consequence, its introduction to the Code of Administrative Procedure was postulated by T. Frey ${ }^{28}$, Z. Kmieciak ${ }^{29}$, W. Federczyk ${ }^{30}$, among others, who argued mediation has important effects on the perception of relations between a citizen and administration as partners, abandoning control for the sake of dialogue. ${ }^{31}$ Z. Kmieciak emphasises the fact that the cooperation of citizens and public administrative authorities should be seen as conforming to the idea of good governance. ${ }^{32}$ The author points out: 'There is space for mediation in public administration wherever there is a divergence of positions and the law offers room for manoeuvre by exchange of arguments, verification of statements and evaluations, concessions or corrections to earlier arrangements (decisions)' ${ }^{33}$ Such situations arise in the area of administrative approval and a variety of clearance decisions at stages of establishing facts or interpretation of vague concepts. The 'privatisation' of public law is noted in the institution as well. ${ }^{34}$

In these circumstances, the traditional, bureaucratic model of public administration was increasingly criticised and seen as anachronistic. ${ }^{35}$ Controlling and unilateral actions of authorities were found not only costly and time-consuming but also not quite effective at eliminating conflicts. On the other hand, failure to resort to all available tools of dialogue with citizens in conflict situations turns more and more frequently against the state and its administrative structures. ${ }^{36}$

Criticism of introducing mediation to administrative proceedings could be heard as well. ${ }^{37}$ The arguments have been collected by S. Gajewski ${ }^{38}$, who emphasises that administrative proceedings are inquisitorial, not contradictory in their essence. Disputes concerning rights between a party and a public administrative authority

28 T. Frey, Office - Citizen Relation..., op. cit., p. $173 \mathrm{ff}$.

Z. Kmieciak, Mediation and Conciliation..., op. cit., p. $173 \mathrm{ff}$.

30 W. Federczyk, Mediation and Conciliation and Court Administrative Procedure, Warszawa 2013, p. 225 ff.

31 A. Korybski, M. Myślińska, Equity of Mediation Proceedings in the Light of the Discourse Theory, "Studia Iuridica Lublinensia" 2011, 15, p. 60.

32 Z. Kmieciak, W poszukiwaniu modelu postępowania odpowiadającego naturze administracji publicznej, „Państwo i Prawo" 2015, 11, p. 13; idem, Dylematy reformy prawa o postępowaniu administracyjnym, „Państwo i Prawo" 2016, 1, p. 7.

Z. Kmieciak, Mediation in Polish..., op. cit., p. 40.

34 A. Kalisz, Mediacja administracyjna i sq̨dowoadministracyjna, „Państwo i Prawo” 2018, 3, p. 22.

35 H. Zięba-Załucka, Demokracja a biurokracja, "Samorząd Terytorialny” 2011, 7-8, pp. 40-45.

36 J. Żołądź, Bariery rozwoju mediacji w sferze administracji publicznej w Polsce. Refleksje teoretyczno-praktyczne, „ADR Arbitraż i Mediacja” 2012, 2, p. 64.

37 Z. Kmieciak, Mediation and Conciliation..., op. cit., pp. 33-64; W. Federczyk, Mediacja w postępowaniu administracyjnym..., op. cit., pp. 225-234.

38 P. Gajewski, Code of Administrative Procedure. New Institutions: Comments on Chapters 5a, 8a, 14 and Sections IVa and VIIIa, Code of Administrative Procedure, Warszawa 2017, Legalis/el, pp. 4-5. 
are not the point of administrative proceedings, therefore, parties to disputes are not of equal status.

Subsequent arguments assumed that a public administrative authority is not empowered to establish facts relative to case resolution together with a party, since the resolution is determined by absolutely prevailing legislation. Parties, even if their interests are in conflict, would be unable to determine a method of case settlement through a third party (mediator), as it is the sole competence of an authority conducting proceedings. It has also been raised that the assignment of attributes of a party to mediation to an administrative authority is at odds with the stereotype of public duty and role of the state that has evolved over the years. ${ }^{39}$

It was also pointed out that the adequate use of existing legal solutions, combined with changes to the conduct of administrative authorities, can bring comparable results by reducing the incidence of disputes between parties and authorities administering proceedings. ${ }^{40}$

\section{Reasons for Introducing Mediation to Administrative Proceedings}

Regardless of the negative arguments discussed above, the legislator has decided to introduce mediation to administrative proceedings under the Act of 7 April 2017 Amending the Code of Administrative Procedure and Certain Other Acts. ${ }^{41}$

This step not only addressed the postulates of the doctrine, but it also implemented a recommendation of the Committee of Ministers of the Council of Europe of 5 September 2001, $\operatorname{Rec}(2001) 9$, on alternative means of resolving court disputes between administrative authorities and private persons (parties). ${ }^{42}$

The amendments to the Code of Administrative Procedure followed the doctrine to assume that introducing mediation would contribute to 'a more partner-based approach of the administration to citizens' and ensure the participation of 'society in administrative control'.43 It was also indicated that mediation may, by explicating rationale and legal grounds of a resolution, help to prevent its review. Therefore, a potential utility of mediation in the realisation of the persuasion principle is

\footnotetext{
39 Z. Kmieciak, Mediation in Polish..., op. cit., p. 63.

40 W. Federczyk, Mediacja w postępowaniu administracyjnym..., op. cit., p. 234.

41 O.J. item 935. T. Frey, Office-Citizen Relation..., op. cit., p. 173.

42 Statement of reasons, pp. 35-36.

43 Statement of reasons, pp. 5 and 36, and J. Wegner-Kowalska, Gtówne idee projektu nowej kodyfikacji postępowania administracyjnego, "Administracja. Teoria-Dydaktyka-Praktyka” 2015, 3, p. 225.
} 
evident. The draft legislators also intended differences of opinions regarding methods of case resolution between the parties to proceedings and administrative authorities to be settled in an amicable manner as early as at the stage of administrative proceedings, which could prevent the instigation of court administrative proceedings.

The possibility of mediation in processes of law application has been treated as a consequence of the principle of common weal as expressed by Article 1 of the Constitution of the Republic of Poland. ${ }^{44}$ The principle is connected to the possible participation of citizens in decisions about public affairs and processes of law application by state authorities. ${ }^{45}$ Administrative authorities should therefore treat private entities as partners, which does not mean compulsory addressing of all their claims or petitions, or making illegal arrangements. The constitutional axiology provides foundations for allowing private entities to take part in determining resolutions that affect them, all the more so as administration - when enforcing law and exercising control - is tasked with i.a. realising subjective rights. ${ }^{46}$ This is not even contrary to the option of their subsequent compulsory enforcement.

Mediation can thus contribute to the building of a social order based on responsibility and participation ${ }^{47}$. It should be seen as part of the realisation of systemic assumptions underpinning the model of democratic rule of law in the practice of law application. The constitutional regulation defining Poland as a democratic Rechtsstaat that incorporates the principles of social justice determines the standard of actions by public authorities that will reinforce citizens' trust in state authorities. Such trust can be achieved where resolutions by public authorities are results of procedures that allow the addressees of the authorities' actions not only to submit their opinions about their cases, but also to take an active part in arriving at resolutions. A presentation of a party's position must be considered insufficient. ${ }^{48}$

The so-called organisational culture of an administrative authority ${ }^{49}$ and the need for an authority to become closer to citizens are also very important and could

44 M. Tabernacka, Direct Citizen Participation in Determining Public Authorities' Resolutions in Mediation Proceedings in Public Administration as an Element of Civic Society, [in:] J. Blicharz, J. Boć (eds.), Prawna działalność instytucji spoteczeństwa obywatelskiego, Wrocław 2009, p. 626.

45 M. Tabernacka, Mediations - Counteracting Divisions in the Practice of Law Application, [in:] M. Tabernacka (ed.), Mediacje ponad podziałami, Wrocław 2013, p. 17.

46 M. Tabernacka, Direct Citizen Participation..., op. cit., p. $627 \mathrm{ff}$.

47 M. Tabernacka, Open Society and Mediation, [in:] M. Tabernacka, R. Raszewska-Skałecka (eds.), Mediacje w spoleczeństwie otwartym, Wrocław 2012, pp. 17 and 18.

48 M. Tabernacka, Mediations - Counteracting Divisions..., op. cit., p. 18.

49 M. Tabernacka, Mediators and Mediating Institutions in the Administration Environment, "Review of Law and Administration" 2017, 111, p. 183. 
lead to a 'warmer' image of the public administration and mutual party-authority relations. ${ }^{50}$ Therefore, this is not solely about the efficiency of administrative proceedings ${ }^{51}$, partner relations between an authority and a citizen, but also about replacement of the control principle with the principle of joint dialogue. Informal operation prior to proceedings proper is an equally important consideration. ${ }^{52}$

\section{Barriers to the Correct Functioning of Mediation}

Although the introduction of mediation to administrative proceedings satisfied postulates of the doctrine that emphasised such a necessity, opinions were also raised that administrative law is not an area conducive to mediation. ${ }^{53}$

Control of an administrative authority and the associated administrative compulsion are indicated as fundamental arguments against mediation in administrative proceedings. It should be noted, however, that arrangements can be made at an earlier stage of establishing rights and duties. In addition, as part of negotiations an authority takes not controlling but factual actions that may result in a controlling administrative act which determines the rights and duties of a decision recipient. Therefore, it seems that the issue of control and potential for compulsion do not impede the application of mediation.

The rule of law and objective truth are some more elements proposed as limiting mediation in administrative cases. ${ }^{54}$ The acceptability of the participation of an authority conducting proceedings is a structural part of mediation which is not suited to the prevailing formula of administrative proceedings. Where mediation is applied, a case is explicated and instantiated as part of 'determining a method of dealing with the case', not of the formula of unilateral and controlling action of an authority. By joining mediation as a participant, an authority somehow yields some of its competences to a mediator with regard to preliminary investigation.

A statutory definition of 'mediation' is absent from the Polish legal framework. ${ }^{55}$ However, the institution of mediation, as incorporated in the Code of Administrative

50 A. Kordik, Mediacja w postępowaniu administracyjnym - uwagi de lege lata i de lege ferenda, „ADR Arbitraż i Mediacja" 2019, 3, p. 47 ff.

51 J. Wegner-Kowalska, Mediation, [in:] Z. Kmieciak (ed.), An Expert Team Report for 2012-2016. Reform of the Administrative Proceedings Legislation, Warszawa 2017, p. $73 \mathrm{ff}$.

52 Z. Kmieciak, Mediation and Conciliation..., op. cit., p. 58.

53 W. Federczyk, Mediacja..., op. cit., p. 63.

54 M. Myślińska, Mediator w polskim porządku prawnym, Warszawa 2018, Ch. II $§ 5$.

55 R. Morek, [in:] E. Gmurzyńska (ed.), Mediacje. Teoria i praktyka, Warszawa 2014, p. 18. 
Procedure, matches its typical theoretical characteristics, i.e. it is voluntary, confidential and conducted by an impartial third party (mediator) ${ }^{56}$. The principle of voluntariness ${ }^{57}$ should be seen as fundamental, since it is participants who decide whether they wish for mediation in their case, they have the right to select a mediator and may withdraw from mediation at any time without adverse legal effects. ${ }^{58}$

It should be pointed out the principle of voluntary mediation is not limited as to subjects ${ }^{59}$, which means it applies to all participants, including the authority that conducts proceedings. Unfortunately, the Code of Administrative Procedure fails to address situations where an authority refuses consent to mediation and only stipulates that mediation is not undertaken if one or more parties refuse to consent by dates to be laid down by the authority in a notice of potential mediation (Article 96b §3 in conjunction with Article 96c of the Code of Administrative Procedure). In this regard, doubt arises as to whether an authority conducting administrative proceedings can refuse to join mediation in a case or whether it is always obliged to take part in mediation proceedings if only the parties to proceedings express such a desire. ${ }^{60}$

The problem of limiting the principle of voluntariness in respect of the authority has been noted by researchers, although some authors make no distinction between the legal positions of an authority and other mediation participants in this regard. ${ }^{61}$ M. Kiełbus is pertinent in indicating that in the context of voluntary mediation, it is not completely clear whether an authority has full discretion when considering requests for mediation, given the way Article 13 of the Code of Administrative Procedure and the duties of an authority conducting proceedings set out there are phrased. This means an authority is free to dismiss such a request from a party. ${ }^{62}$

56 Cf. Ch.W. Moore, Mediation: Practical Strategies of Conflict Resolution, Warszawa 2016, p. 41; M. Wilbrandt-Gotowicz, Mediacja w postępowaniu administracyjnym jako nowy instrument prawny, [in:] J. Jagielski, M. Wierzbowski (eds.), Prawo administracyjne dziś i jutro, Warszawa 2018, p. 248; J. Żołądź, Bariery rozwoju mediacji..., op. cit., p. 65; I. Fisz, Mediacja w postępowaniu administracyjnym - wybrane uwagi „ „Casus” 2017, 87, p. 40.

57 K. Celińska-Grzegorczyk, [in:] R. Hauser, M. Wierzbowski, Code of Administrative Procedure: Commentary, Legalis/el, 2018, Article 96a, thesis 6.

58 S. Gajewski, Code of Administrative Procedure..., op. cit., thesis I to Article 96a.

59 A. Kocot-Łaszczyca, G. Łaszczyca, Zasady postępowania mediacyjnego w ogólnym postępowaniu administracyjnym, Warszawa 2018, p. 43.

60 K. Radosz, Prawna ocena braku zgody na mediacje, "Casus", 93, p. 28.

61 B. Adamiak, [in:] J. Borkowski, Code of Administrative Procedure: Commentary, Legalis/el., 2017, Article 96a; P.M. Przybysz, Code of Administrative Procedure: Updated Commentary, LEX/el., 2019, Article 96a.

62 M. Kiełbus, [in:] A. Legat, Code of Administrative Procedure - Practical Discussion of Amendments Effective as of 1 June 2017 - Standardised Text of the Law Highlighting the Amendments, Gdańsk 2017, p. 53. 
Three positions have finally evolved in the doctrine in this connection:

1. The principle of voluntary mediation does not apply to an administrative authority at all ${ }^{63}$

2. The principle of voluntary mediation is limited with regard to an authority, as it cannot go against the grain of the regulation laid down by Article 13 of the Code of Administrative Procedure. ${ }^{64}$

3. Voluntary mediation, an overarching principle of mediation, is not in any way limited as regards an authority participating in mediation. ${ }^{65}$

It is my belief that the second of the options should be accepted, since Article 13 of the Code of Administrative Procedure implies that an authority 'aims for' amicable resolution of disputed cases if their nature allows it. Thus, the regulation expresses an authority's undertaking to attempt amicable resolution of disputed issues. It is therefore difficult to permit an authority to object to mediation without reason, if only the nature of a case admits mediation.

The characteristic of voluntariness can prove a defect, on the other hand, since participants may take advantage of mediation to protract proceedings in order to obtain information that they would be unable to secure as part of traditional proceedings, and then, even without using the information directly, to base continuation of the proceedings on such information.

The mediation solutions introduced may also fail expectations because the legislator has neglected to make parallel amendments to other regulations that determine such proceedings, i.e. their principles, object, or to implement the new form of administrative action, namely an administrative contract.

The current regulation apparently admits of mediation in a broad range of cases. However, due to the characteristic grounding of administrative law in imperative norms, the practical application of mediation is severely limited. Contrary to dispositive norms in private law, public legislation does not provide for freedom of legal relations ${ }^{66}$ Most administrative regulations are based on the principle of

63 A. Jakubowski, [in:] M. Wierzbowski, A. Wiktorowska, Code of Administrative Procedure: Commentary, Legalis/el., 2018, Article 96a, thesis 10, and M. Wilbrandt-Gotowicz, [in:] A. Wróbel, M. Jaśkowska, Updated Commentary on the Code of Administrative Procedure, LEX/el, 2018, Article 96a, thesis 7.

64 J.G. Firlus, K. Klonowski, Mediacja wogólnym postępowaniu administracyjnym, „Casus” 2017, 86, p. 18, and A. Kocot-Łaszczyca, G. Łaszczyca, Zasady postępowania mediacyjnego w ogólnym..., op. cit., p. 43.

65 S. Gajewski, Code of Administrative Procedure..., op. cit., thesis VII to Article 96a, and J.E. Kulikowska-Kulesza, D.J. Kościuk, A.K. Modrzejewski, Organ administracji publicznej w postępowaniu mediacyjnym, [in:] J. Jagielski, M. Wierzbowski (eds.), Prawo administracyjne dziś i jutro, Warszawa 2018, p. 446.

66 A. Błaś, [in:] J. Boć (ed.), Public Administration, Wrocław 2004, pp. 223-228. See also: J. Boć, [in:] J. Boć (ed.), Administrative Law, Wrocław 2010, pp. 40-43. 
binding, which means an authority, after establishing that facts of a case conform to a legal norm's hypothesis, is bound to resolve as provided for by the norm. ${ }^{67}$

It should also be remembered that the institution of mediation cannot be employed in every case, even potentially liable to an amicable resolution. ${ }^{68}$ This is primarily true of the so-called 'non-negotiable goods', where protection of especially important values, such as human life or health, is at stake. Non-negotiable goods also comprise abstract values, such as ideas, morality or religion. ${ }^{69}$ Cases whose objects relate to states of necessity or where decisions must be promptly enforced are not negotiable either.

Social, organisational and educational barriers need to be mentioned in addition to the legal issues. Insufficient social trust ${ }^{70}$ and education in the matter must be stressed. Meanwhile, skilful management of administrative disputes requires officials to possess not only professional know-how but also certain predispositions and interdisciplinary competences in the field of conflict management as well as social psychology, communication, rhetoric, and diplomacy. ${ }^{71}$

\section{Advantages of Mediation and Potential for Its Application}

It is still too early for a definite assessment of introducing mediation to the administrative procedure, yet certain positive aspects can be identified. First of all, it should be stressed that it offers some opportunities for resolving conflicts in administrative cases and preventing disputes that may become sources of more cases. Putting an end to a conflict at an earlier stage provides opportunities for reducing the number of administrative cases to be heard by courts.

The fact that parties work out methods of resolving their own conflicts, instead of arbitrary decisions imposed by authorities, is a major advantage of mediation. Added to this, solutions can be better suited to individual needs of participants in mediation, while solutions agreed upon by parties are more satisfactory. The parties are also more eager to discharge obligations that they accept as part of mediation.

67 J. Zimmermann, Administrative Law, Warszawa 2018, p. 64, 65.

68 Regional Administrative Court in Cracow Judgment of 22 March 2018, Ref. No. II SA/Kr 180/18, Legalis, No. 1755159.

69 M. Tabernacka, Negotiation and Mediation in the Public Domain, Warszawa 2018, pp. 23 and 59.

$70 \quad$ J. Żołądź, Bariery rozwoju mediacji..., op. cit., p. 67.

71 Cf. M. Żukowski, Problematyka wyksztatcenia urzędników państwowych i samorządowych, „Samorząd Terytorialny" 2010, 10, pp. 37-45. 
Reducing the stress of conflict resolution and free formulation of the terms and conditions of arrangements and decisions are some more indisputable advantages of mediation ${ }^{72}$. Mediation helps to concentrate evidence as well.

Mediation also fulfils the principle of inducing citizens' trust in the public authority and corresponds to the requirements of civic participation in the exercise of power. Expanded potential for the public participation in the decision-making by public administration is a major consequence of the change to administrative proceedings. Obviously, this does not mean that the status of entities outside organisational structures of public administration has become equal to that of public administrative authorities, since asymmetry in this respect continues. By regulating mediation in the Code, however, the legislator attempts to reconcile the need to assure public law and order and the parallel need for the increasingly democratic nature of public administration. ${ }^{73}$ The acceptance of the fact that each human being is capable of deciding their own needs and interests consciously and independently is a key assumption.$^{74}$ In the case of mediation, considering positions, interests and ambitions of parties, not merely an arbitrary resolution of a conflict as proposed by a given entity within the law, is of the essence as part of mediation. ${ }^{75}$ By abandoning possibilities of control for the sake of dialogue, a public administration authority signals to parties to proceedings their opinions are found important for resolution of a case. ${ }^{76}$

Thus, not solely raising the quality or quantity of services, but reducing the burden of public administration felt by society becomes the chief objective of the administration. ${ }^{77}$

Mobilisation of citizens, encouraged to participate in different areas of the state operation, is a major part of the concept of democratic rule of law. If members of the public, who are parties to mediation as part of administrative proceedings, are able to work out lawful compromises with public administrative authorities or with one another, they will contribute to development of the civic society, where

72 M. Bobrowicz, Mediacja. Jestem za, Warszawa 2008, p. 40.

73 M. Tabernacka, Kulturowo-antropologiczna mediacyjność organów konsensualnych, „The Opole Studies in Administration and Law" 2018, 16, 1(4), p. 109.

74 W. Federczyk, Mediacja..., op. cit., p. 54.

75 M. Tabernacka, An Opinion Concerning a Proposed Mediation Submitted as Part of Team Work, [in:] Z. Kmieciak, Reform of the Administrative Proceedings Legislation: An Expert Team Report for 2012-2016, Warszawa 2017, http://www.nsa.gov.pl/archiwum-aktualnosci/uzupelniony-raport-ekspercki-nt-reforma-prawa-o-postepowaniu-administracyjnym,news,27,327.php?p=8 (as of 1 February 2020), p. 486.

76 R. Hauser, M. Wierzbowski (eds.), Code of Administrative Procedure: Commentary, Warszawa 2018, p. 699.

77 M.Stasz, Optymalizacja działania administracji publicznej dzięki wykorzystaniu mediacji w postępowaniu administracyjnym, „ADR Arbitraż i Mediacja” 2020, 1, p. 41. 
a citizen is not only an entity being administered but also takes an active part in public affairs and the determination of legal relations. ${ }^{78}$ By cooperating with society, public administration is better prepared to adapt its functioning to changing social conditions and adequately respond to needs emerging in society. ${ }^{79}$

Increasing decision-making capacities of citizens can not only change the public attitude to public administration authorities and improve their image, but they can also provide a better guarantee of a permanent resolution of disputes and their causes, since the parties concerned and public administration authorities are participants. ${ }^{80}$

The social benefits of mediation discussed above result in the improved realisation of the general principles of administrative proceedings, in particular, the principles of trust, persuasion and amicable case settlement. The participation of the public in the decision-making processes of public administration is a distinct benefit in itself. This is an important part of the process of the empowerment and independence of members of the public in relation to the public authorities. It is, in fact, the fullest realisation of the public interest.

\section{Conclusions}

Mediation, owing to its fundamental characteristic of finding a resolution to a dispute by parties themselves with a mediator's aid, has so far been mainly applied to private law, where parties are equal and disputes are disposable, as their sources are in the parties' autonomous status. In administrative law, on the other hand, with an authority in a superior, controlling position, the history of mediation is only commencing.

The nature of administrative relation, with extensive powers of administrative authorities, certainly is not conducive to forms relying on consensus. Given the nature of administrative action, which is at present shifting from controlling to consensual, these forms should be seen as alternatives to the traditionally superior role of administrative authorities. The legislator is correct in concluding that, although a controlling authority unilaterally determines rights and duties by way of administrative decisions, there is still room for declarations of parties' will.

A successful implementation of mediation to administrative proceedings will largely depend on the attitudes of parties and authorities. In spite of these doubts,

\footnotetext{
78 M. Tabernacka, Direct Citizen Participation..., op. cit., pp. 626-627 and 634.

79 M. Tabernacka, An Opinion Concerning..., op. cit., p. 487.

80 W. Federczyk, Mediacja..., op. cit., p. 54.
} 
it seems that mediation can constitute an effective instrument of eliminating conflicts in administration. However, administrative staff needs adequate preparation - since this is administration, for whom mediation is indubitably both a processual and mental challenge - that will play a decisive role in implementing mediation to administrative cases. It is essential, though, that an opportunity has been created for transforming the nature of administration from controlling to mediating and more friendly to subjects administered.

\section{Bibliography}

Adamiak B. [in:] B. Adamiak, J. Borkowski, Code of Administrative Procedure: Commentary, Warszawa 2019.

Adamiak B. [in:] J. Borkowski, Code of Administrative Procedure: Commentary, Legalis/el., 2017.

Błaś A. [in:] J. Boć (ed.), Public Administration, Wrocław 2004.

Bobrowicz M. Mediacja. Jestem za, Warszawa 2008.

Boć J. [in:] J. Boć (ed.), Administrative Law, Wrocław 2010.

Borkowski J., The Notion of Administrative Control, "Acta Universitatis Wratislaviensis, Review of Law and Administration II" 1972, 167.

Bródka A., Dopuszczalność oraz zakres prowadzenia mediacji w postępowaniu administracyjnym, „ADR Arbitraż i Mediacja” 2020, 1.

Celińska-Grzegorczyk K. [in:] R. Hauser, M. Wierzbowski, Code of Administrative Procedure: Commentary, Legalis/el, 2018.

Federczyk W., Mediacja w postępowaniu administracyjnym, Warszawa 2013.

Firlus J.G., Klonowski K., Mediacja w ogólnym postępowaniu administracyjnym, "Casus" $2017,86$.

Fisz I., Mediacja w postępowaniu administracyjnym - wybrane uwagi, "Casus” 2017, 87.

Frey T., Office - Citizen Relation and Good Administrative Standards, Warszawa 2007.

Gajewski P., Code of Administrative Procedure. New Institutions: Comments on Chapters 5a, 8a, 14 and Sections IVa and VIIIa, Code of Administrative Procedure, Warszawa 2017, Legalis/el.

Głąba P.M., Mediacyjna koncepcja ustalania stanu faktycznego w postępowaniu administracyjnym, „ADR Arbitraż i Mediacja” 2012, 3.

Hauser R., Wierzbowski M. (eds.), Code of Administrative Procedure: Commentary, Warszawa 2018.

Jakubowski A. [in:] M. Wierzbowski, A. Wiktorowska, Code of Administrative Procedure: Commentary, Legalis/el., p. 201.

Jaśkowska M. [in:] R. Hauser, Z. Niewiadomski, A. Wróbel (eds.), Instytucje prawa administracyjnego. System prawa administracyjnego, Vol. 1, Warszawa 2010. 
Kalisz A., Mediacja administracyjna i sądowoadministracyjna, „Państwo i Prawo” 2018, 3.

Kiełbus M. [in:] A. Legat, Code of Administrative Procedure - Practical Discussion of Amendments Effective as of 1 June 2017 - Standardised Text of the Law Highlighting the Amendments, Gdańsk 2017.

Klonowski K. [in:] H. Knysiak-Sudyka (ed.), Code of Administrative Procedure: Commentary, Warszawa 2019.

Kmieciak Z., Dylematy reformy prawa o postępowaniu administracyjnym, „Państwo i Prawo” 2016, 1 .

Kmieciak Z., W poszukiwaniu modelu postępowania odpowiadającego naturze administracji publicznej, „Państwo i Prawo” 2015, 11.

Kmieciak Z., Postępowanie mediacyjne i uproszczone przed sądem administracyjnym, „Państwo i Prawo" 2003, 10.

Kmieciak Z., Mediation in Polish Administrative Law, [in:] H. Machińska (ed.), Mediation in Administrative Cases, Warszawa 2007.

Kmieciak Z., Mediation and Conciliation in Administrative Law, Cracow 2004.

Kocot-Łaszczyca A., Łaszczyca G., Zasady postępowania mediacyjnego w ogólnym postępowaniu administracyjnym, Warszawa 2018.

Kordik A., Mediacja w postępowaniu administracyjnym - uwagi de lege lata i de lege ferenda, „ADR Arbitraż i Mediacja” 2019, 3.

Korybski A., Myślińska M., Equity of Mediation Proceedings in the Light of the Discourse Theory, "Studia Iuridica Lublinensia" 2011, 15.

Kowalczyk K., Instytucja mediacji i jej znaczenie w administracji publicznej, „ADR Arbitraż i Mediacja" 2019, 2.

Krawczyk A., AdministrativeProcedural Law, "System of Administrative Law" 2014, 9.

Kulikowska-Kulesza J.E., Kościuk D.J., Modrzejewski A.K., Organ administracji publicznej w postępowaniu mediacyjnym, [in:] J. Jagielski, M. Wierzbowski (eds.), Prawo administracyjne dziś i jutro, Warszawa 2018.

Łętowski J., Prawo administracyjne dla każdego, Warszawa 1995, pp. 184-185.

Majchrzak B., Problems of Defining Administrative Law (Based on Views in the Doctrine), "Public Law Quarterly" 2006, 3.

Moore Ch.W., Mediation: Practical Strategies of Conflict Resolution, Warszawa 2016.

Morek R. [in:] E. Gmurzyńska (ed.), Mediacje. Teoria i praktyka, Warszawa 2014.

Myślińska M., Mediator w polskim porządku prawnym, Warszawa 2018.

Ochendowski E., Prawo administracyjne. Część ogólna, Torun 1999.

Płeszka K., Araszkiewicz M. [in:] M. Araszkiewicz, J. Czapska, M. Pękala, K. Płeszka (eds.), Mediacja. Teoria, normy, praktyka, Warszawa 2017.

Przybysz P.M., Code of Administrative Procedure: Updated Commentary, LEX/el., 2019.

Radosz K., Prawna ocena braku zgody na mediację, „Casus” 2019, 93/2019.

Radziewicz P., Administrative Legal Concept of Public Control, "Public Law Quarterly" 2005,4 . 
Skóra A., The Idea of Mediation in Administrative Proceedings, "Mediator" 2004, 29(2).

Skrzydło-Niżnik I., Essence and Types of Controlling Powers of State Administration, "Cracow Law Studies" 1987, 20.

Smarż J., Instytucja mediacji w postępowaniu administracyjnym, "The Opole Studies in Administration and Law" 2018, 16, 1(4).

Starościak J., System prawa administracyjnego, Vol. III, T. Rabska, J. Łętowski (eds.), Warszawa 1977.

Stasz M., Optymalizacja działania administracji publicznej dzięki wykorzystaniu mediacji w postępowaniu administracyjnym, „ADR Arbitraż i Mediacja” 2020, 1.

Szreniawski J., Zagadnienia relacji pracowników administracji publicznej z obywatelami w modernizujacym się państwie, „Administracja. Teoria-Dydaktyka-Praktyka” 2011, 4(25).

Tabernacka M., An Opinion Concerning a Proposed Mediation Submitted as Part of Team Work, [in:] Z. Kmieciak, Reform of the Administrative Proceedings Legislation: An Expert Team Report for 2012-2016, Warszawa 2017, http://www.nsa.gov.pl/archiwum-aktualnosci/uzupelniony-raport-ekspercki-nt-reforma-prawa-o-postepowaniu-administracyjnym,news, 27,327.php? $\mathrm{p}=8$ (as of 1 February 2020).

Tabernacka M., Kulturowo-antropologiczna mediacyjność organów konsensualnych, "The Opole Studies in Administration and Law" 2018, 16, 1(4).

Tabernacka M., Direct Citizen Participation in Determining Public Authorities' Resolutions in Mediation Proceedings in Public Administration as an Element of Civic Society, [in:] J. Blicharz, J. Boć (eds.), Prawna działalność instytucji społeczeństwa obywatelskiego, Wrocław 2009.

Tabernacka M., Mediations - Counteracting Divisions in the Practice of Law Application, [in:] M. Tabernacka (ed.), Mediacje ponad podziałami, Wrocław 2013.

Tabernacka M., Mediators and Mediating Institutions in the Administration Environment, "Review of Law and Administration" 2017, 111.

Tabernacka M., Open Society and Mediation, [in:] M. Tabernacka, R. Raszewska-Skałecka (eds.), Mediacje w spoteczeństwie otwartym, Wrocław 2012.

Tabernacka M., Negotiation and Mediation in the Public Domain, Warszawa 2018.

Talma W., Mediation as an Alternative Method of Dispute Resolution, "Casus" 2019, 92.

Taras W., Power - Public Administration - Trust, [in:] Administrative Control. Public Administration in the Spheres of Empire and Dominion, Rzeszów 2012.

Wegner-Kowalska J., Główne idee projektu nowej kodyfikacji postępowania administracyjnego, "Administracja. Teoria-Dydaktyka-Praktyka” 2015, 3.

Wegner-Kowalska J., Mediation in Administrative Cases - Questions and Doubts, "Research Papers of Administrative Judicature" 2017, 6.

Wegner-Kowalska J., Mediation, [in:] Z. Kmieciak (ed.), An Expert Team Report for 2012-2016. Reform of the Administrative Proceedings Legislation, Warszawa 2017.

Wegner-Kowalska J., The Case for Including Mediation in the Code of Administrative Procedure, "Public Law Review" 2016, 11. 
Wegner-Kowalska J., The Idea of Mediation in Administrative Proceedings, "Public Law Review" 2016, 10.

Wilbrandt-Gotowicz M., Mediacja w postępowaniu administracyjnym jako nowy instrument prawny, [in:] J. Jagielski, M. Wierzbowski (eds.), Prawo administracyjne dziś i jutro, Warszawa 2018.

Wilbrandt-Gotowicz M., [in:] A. Wróbel, M. Jaśkowska, Updated Commentary on the Code of Administrative Procedure, LEX/el, 2018.

Wójcik A., Mediacja jako nowy instrument znowelizowanego kodeksu postępowania administracyjnego w ksztattowaniu nowoczesnej administracji, „Młody Jurysta” 2018, 4.

Zięba-Załucka H., Demokracja a biurokracja, "Samorząd Terytorialny" 2011, 7-8.

Zimmermann J., Administrative Law, Warszawa 2018.

Zimmermann M., Pojęcie administracji publicznej a "swobodne uznanie", Poznań 1959.

Żołądź J., Bariery rozwoju mediacji w sferze administracji publicznej w Polsce. Refleksje teoretyczno-praktyczne, „ADR Arbitraż i Mediacja” 2012, 2.

Żukowski M., Problematyka wykształcenia urzędników państwowych i samorządowych, „Samorząd Terytorialny" 2010, 10.

Reasons for the draft act amending the Code of Administrative Procedure and certain other acts, and draft executive acts, Bill, No. 1183, pp. 34-35.

Regional Administrative Court in Cracow Judgment of 22 March 2018, Ref. No. II SA/ Kr 180/18, Legalis, No. 1755159. 